\title{
INDICATORS OF LEFT VENTRICLE HYPERTROPHY IN PATIENTS WITH ARTERIAL HYPERTENSION COMBINED WITH OBESITY AND THEIR INTERCONNECTION WITH POLYMORPHISM OF LYS198ASN GENE OF ENDOTHELIN-1
}

DOI: 10.36740/WLek202005125

\author{
Yuliia 0. Smiianova, Liudmyla N. Prystupa, Olha M. Chernatska, Yurii V. Smiianov \\ MEDICAL INSTITUTE, SUMY STATE UNIVERSITY, SUMY, UKRAINE
}

\begin{abstract}
The aim of the study was to find dependence of left ventricular hypertrophy indexes to polymorphism of Les198Asn gene endothelin-1 and BMI.

Materials and methods: We took research in 160 patients with arterial hypertension, using ECG and polymerase chain reaction (PCR). Groups were divided additionally according to BMI (body mass index).

Results: It was found, that patients with obesity had their Left ventricular mass and hypertrophy left ventricular indexes higher, than in patients with normal and increased body weight. Carriers of Asn198Asn and Lys198Asn genotypes Left ventricular mass and hypertrophy left ventricular indexes are higher than in carriers of Lys198Lys genotype. Conclusions: It was determined that in patients-carriers of Asn198Asn genotype, Left ventricular mass (LVMI) and hypertrophy left ventricular indexes (LVMMI) were higher compared to patients-carriers of Lys198Lys and Lys198Asn type, both in men and women. The dependence of LVMI and LVMMI are shown to be higher in patients with obesity than in people with normal and increased body mass.
\end{abstract}

KEY WORDS: left ventricular hypertrophy, genes` polymorphism, endothelin-1, Lys198Asn genotype

Wiad Lek. 2020;73(5):972-977

\section{INTRODUCTION}

Left ventricular hypertrophy is pathological thickening of left ventricular myocardium, developed in response to constant stain on heart, usually caused by chronical hypertension [1]. In short-term prospective this structural change leads to heart compensate high hemodynamic stain. However, in long-term prospective lasting left ventricular hypertrophy $(\mathrm{LVH})$ is an independent risk factor of development for numerous vascular pathological states, such as cardiac failure, ischemic heart disease, stroke, arrhythmia, sudden cardiac death, cardio-vascular diseases and correspondent mortality [2].

$\mathrm{LVH}$ frequency in general population equals $3 \%$, in case of arterial hypertension - $7-40 \%$ [9]. According to Kannel W.B. et al. LVH, diagnosted with ECG in patients with blood pressure more than $160 / 95$ is met 10 more often than in norma-tensive patients [3]. Increasing of left ventricular mass index (LVM) is possible before hypertension develops. Douglas P. et al., (2012) writes that LVH risk can be hereditary and cause hypertension. It is proved that increasing of blood pressure alongside with other factors (high body mass, age, male gender, race, neurohumoral and growth) lead to development and progress $\mathrm{LVH}$. One of the main risk factors of LVH development is presence of comorbid diseases: obesity, which provokes increasing of heart afterload, 2 type diabetes. Decreasing of blood pressure, body mass index lead to decreasing of hypertrophy, and in the case of their absence prevents its development [10].

Endothelin-1 (ET-1) is cardiotropic that is occurred as inotropic influence on myocardium, regulates preload and afterload, leads to increasing of myotic process in myoradium and development of LVH [5-8].

The purpose of this research was defining of indexes of intercardial and system hemodynamics in patients with arterial hypertension, according to polymorphism of Lys198Asn gene endothelin-1. Question of implement of current polymorphism factor on LVH level is relevant and requires further studying to improve treatment tactics.

\section{THE AIM}

Detection of LVH indexes dependence in patients with arterial hypertension from polymorphism Lys198Asn gene endothelin- 1 and body mass index.

\section{MATERIALS AND METHODS}

160 patients with vary arterial hypertension diagnoses of I, II phases 1, 2, 3 levels were examined during the study. Among examined patients were 83 women $(51,9 \%)$ and 77 men $(48,1 \%)$ at the age of $33-87$ years, median (interquartile range) - $67(58-67)$ years. All patients were divided into 3 groups, depending of BMI. I group $\mathrm{BMI}<24,9 \mathrm{~kg} / \mathrm{m}^{2}$; II group $-\mathrm{BMI}=25,0-29,9 \mathrm{~kg} / \mathrm{m}^{2}$; 
III group - BMI $>30,0 \mathrm{~kg} / \mathrm{m}^{2}$. I group consisted of 75 patients, in which 41 women $(54,7 \%)$ and 34 men $(45,3$ $\%)$. Age range of examined patients in I group equaled $68(60-75)$ years. In II group were 48 patients, in which 20 women $(58,3 \%)$ and 28 men $(41,7 \%)$. Age range of examined persons in II group was 65 (54-76) years. In III group 37 patients were included, 22 women $(59,5 \%)$ and 15 men (40,5\%). Age range of examined patients of III group was $65(60-77)$ years.

Dividing of groups according to BMI means anthropometric data varies with statistically significant range of BMI ( $p<0,05$, Kruskal-Wallis). Patients with obesity had following circumference of waist: in women 103 (96-115) $\mathrm{cm}$, in men $108(105-116) \mathrm{cm}$, that indicated abdominal type of obesity.

With ECG analysis, we studied left ventricular end-diastolic dimension (LVEDd), thickness of the interventricular septum (TIS), PWT in M-mode from parasternal access at the level of mitral valve chord along cardial long axis. Left ventricular myocardium mass (LVMM) was calculated by formula Penn Convention: $\mathrm{LVMM}=1,06$ $\times\{[\mathrm{EDD}+\mathrm{DLVPWT}+\mathrm{ISTD}] 3-\mathrm{EDD} 3\}-13,6$ (g). To calculate LVMMI we used formula, recommended by ASE (American Society of Echocardiography) (2005): LVMMI $=\mathrm{LVMM} /$ height $^{2}>^{7}$. To confirm the diagnosis of LVH we examined and compared ECG data: LVMM in women $>162 \mathrm{~g}$, inmen $>224 \mathrm{~g}$; LVMMI in women $>44 \mathrm{~g} / \mathrm{m}^{2}>^{7}$, in men $>48 \mathrm{~g} / \mathrm{m} 2,7$ [13]. Polymorphism of Lys198Asn gene of endothelin-1 was identified with polymerase chain reaction with further analysis of restriction fragments. Data were statistically processed with non-parametric methods, as division of LVMM (left ventricular myocardium mass) and HLVMM (hypertrophy left ventricular myocardium mass) indexes by Gauss were not equal to normal. For description of LVMM and HLMM we used median data and interquartile range (25th and 75th percentiles). To compare mentioned indexes we used rankings ' analysis variation ANOVA by Kruskal-Wallis criteria. Using of this method we checked null hypothesis for absence of difference between groups. If $\mathrm{p}>0,05$, than null hypothesis about median difference absence in groups was proved, that means groups were not different. If $p<0,05$, null hypothesis was not proved, and, correspondently, we got alternative hypothesis that proved median difference in groups. In the last case, we compared groups in pairs with non-parametric Mann-Whitney U-test and Bonferroni correction to evaluation of $\mathrm{p}$-value.

Patients were enrolled in the study after informed consent obtained in accordance with the Helsinki Declaration of the World Medical Association on the Ethical Principles of Scientific and Medical Research. The study was approved by the Bioethics Committee for experimental and clinical studies at Sumy State University Medical Institute.

\section{RESULTS}

At the first stage we analyzed dependence of ECG data from polymorphism Lys198Asn gene of endothelin-1 (Table I).
The results proved that data of LVMM and LVMMI in patents with arterial hypertension and different genotype polymorphism of Lys198Asn of gene endothelin-1 ( $\mathrm{p}_{1}=$ 0,$003 ; \mathrm{p}_{2}=0,008$, Kruskel-Wallis). Carriers of Asn198Asn genotype LVMM is $24 \%$ higher than in patients with Lys198Lys type ( $p=0,001$, Mann-Whitney). Patients with hypertension and Lys198Asn genotype LVMM was 9\% higher to Lys198Lys type ( $p=0,021$, Mann-Whitney). The same tendency is observed among carriers of Lys198Asn and Asn198Asn types, though, it had not been statistically significant ( $\mathrm{p}=0,136$, Mann-Whitney). LVMMI in patients with Asn198Asn genotype is higher compared to data of patients-carriers of Lys198Lys type for $17 \%$ ( $p=0,007$, Mann-Whitney) and 9\% higher in Lys198Asn carriers compared to Lys198Lys ones ( $\mathrm{p}=0,028$, Mann-Whitney). Between carriers of Lys198Asn and Asn198Asn genotypes difference was not statistically significant $(\mathrm{p}=0,121$, Mann-Whitney).

Next phase was checking difference existence of LVMM and LVMMI in men and women depending on genotype polymorphism of Lys198Asn of gene endothelin-1. It is determined that there is difference of LVMM and LVMMI in men depending of genotype $\left(\mathrm{p}_{1}=0,002 ; \mathrm{p}_{2}=0,010\right.$, Kruskel-Wallis). After comparison according to Mann-Whitney method, it was determined that in men-carriers of Asn198Asn genotype LVMM is $31 \%$ higher that in representatives of Lys198Lys type ( $p=0,002$, Mann-Whitney). In patients-men with hypertension and Lys198Asn genotype LVMM is $27 \%$ higher comparing to Lys198Lys ( $\mathrm{p}=0,005$, Mann-Whitney). In carriers of Lys198Asn and Asn198Asn genotypes diffrenve was not statistically significant ( $p=0,394$, Mann-Whitney). LVMMI analysis in men with different genotype polymorphism of Lys198Asn of gene endothelin- 1 it was determined that in men-carriers of Asn 198Asn type LVMMI is $50 \%$ higher than in patients with Lys198Lys ( $p=0,010$, Mann-Whitney). In cariers of Lys 198Asn genotype LVMMI was higher compared to patients with Lys198Lys for 41\% ( $p=0,021$, Mann-Whitney). In patients with arterial hypertension with genotypes Lys198Asn and Asn198Asn difference in LVMMI was not registered ( $p=0,223$, Mann-Whitney) (Fig. 1).

We additionally checked difference presence of LVMM and LVMMI in women with hypertension depending of genotype polymorphism of Lys198Asn of gene endothelin-1. It was found, that difference is typical for women either ( $\mathrm{p}_{1}=0,004 ; \mathrm{p}_{2}=0,010$, Kruskel-Wallis). In women-carriers of Asn198Asn genotype LVMM is 44\% higher than in patients with Lys198Lys ( $p=0,046$, Mann-Whitney). In women with arterial hypertension and Lys198Asn genotype LVMM was higher for $26 \%$ compared to Lys198Lys type ( $p=0,002$, Mann-Whitney). In carriers of Lys198Asn and Asn198Asn types difference had not been statistically significant ( $p=0,547$, Mann-Whitney). LVMMI in women with Asn198Asn genotype is for $54 \%$ higher than in representatives of Lys198Lys genotype $(\mathrm{p}=0,004$, Mann-Whitney). In patients-women with hypertension with Lys198Asn genotype LVMMI was higher compared to Lys198Lys genotype for $43 \%$ ( $\mathrm{p}=0,005$, Mann-Whitney). 
Table I. Median (interquartile range) of ECG indexes of left ventricular myocardium hypertrophy in patients with arterial hypertension, depending on polymorphism Lys198Asn in gene endothelin-1.

\begin{tabular}{ccc}
\hline Genotype & Left Ventricular Mass, $\mathbf{g}$ & Left Ventricular Mass index, $\mathbf{g} / \mathbf{m}^{\mathbf{2}, \mathbf{7}}$ \\
\hline Lys198Lys $(\mathrm{n}=74)$ & $243(183-300)$ & $73(42-88)$ \\
\hline Lys198Asn $(\mathrm{n}=73)$ & $290(201-332)$ & $81(47-90)$ \\
\hline$(\mathrm{n}=13)$ & $320(285-360)$ & $89(84-94)$ \\
\hline $\mathrm{p}$ (Kruskal-Wallis) & $\mathrm{p}<0,003$ & $\mathrm{p}=0,008$ \\
\hline
\end{tabular}

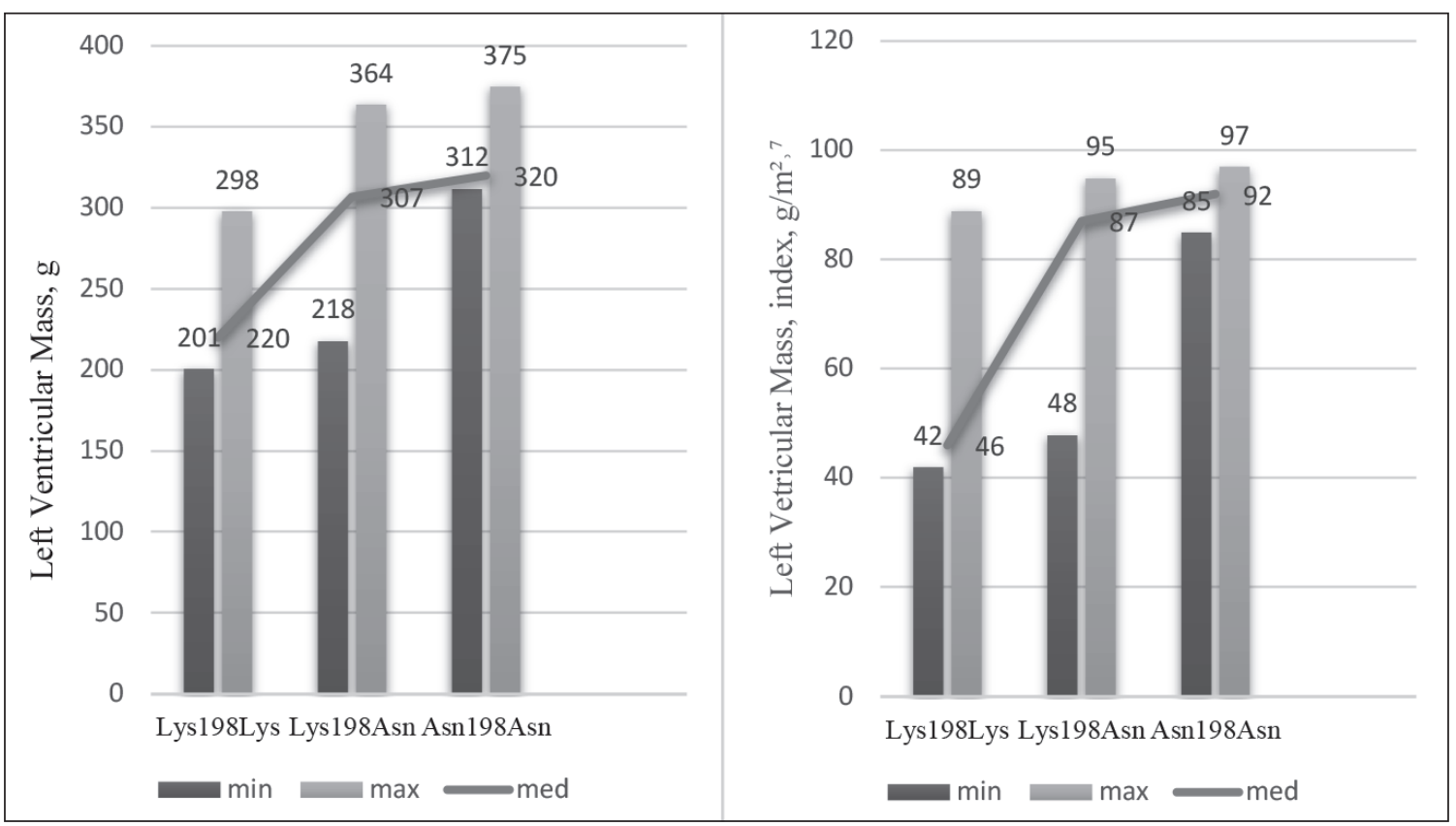

Fig. 1. Median (interquartile range) of ECG indexes in men depending on polymorphism of Lys198Asn in gene endothelin-1.

In women with hypertension and genotypes Lys198Asn and Asn198Asn difference in LVMMI was not registered ( $\mathrm{p}=0,460$, Mann-Whitney) (Fig. 2).

Alongside with studying dependence of ECG data from Lys198Asn polymorphism, we took research on dependence of these data from BMI (Table II).

Results' analysis showed presence of difference of LVMM and LVMMI data according to studied groups ( $\mathrm{p}_{1}$ $<0,001 ; \mathrm{p}_{2}=0,002$, Kruskel-Wallis). In III group patients LVMM data were $18 \%$ and $16 \%$ higher than in patients of I and II groups correspondently $\left(\mathrm{p}_{1}<0,001 ; \mathrm{p}_{2}=\right.$ 0,004, Mann-Whitney). Difference between results of I and II groups were not statistically significant $(\mathrm{p}=0,260$, Mann-Whitney). LVMMI in patients of III group is $11 \%$ higher compared to results of I group ( $p<0,001$, МаннаУітні) and $8 \%$ compared to II ( $\mathrm{p}=0,026$, Mann-Whitney).). Difference between results of I and II groups were not statistically significant ( $\mathrm{p}=0,218$, Mann-Whitney).

We also studied dependence of LVMM and LVMMI from $\mathrm{BMI}$ in men. It was proved that both indexes differ by the formed by BMI group for study $\left(\mathrm{p}_{1}<0,001 ; \mathrm{p}_{2}=0,001\right.$, Kruskel-Wallis). LVMM in III group is $45 \%$ higher compared to I ( $\mathrm{p}<0,001$, Mann-Whitney), in II group index is $24 \%$ increased compared to the same group ( $\mathrm{p}<0,050$, Mann-Whitney). In III group LVMM is $25 \%$ increased compared to LVMM in II ( $\mathrm{p}=0,003$, Mann-Whitney).
LVMMI in III group is higher for 53\% and $16 \%$ correspondently compared to I and II groups ( $\mathrm{p}_{1}<0,001, \mathrm{p}_{2}=0,004$, Mann-Whitney), in II group current index is also increased compared to I, however, this difference is not statistically significant ( $p=0,237$, Mann-Whitney) (Fig. 3).

In women LVMM and LVMMI also differ dependently to BMI ( $\mathrm{p}_{1}<0,008 ; \mathrm{p}_{2}=0,004$, Kruskel-Wallis). LVMM in II group was $23 \%$ increased compared to I ( $p=0,004$, Mann-Whitney), in III group current index was $44 \%$ higher compared to the same group ( $p=0,023$, Mann-Whitney). In III group LVMM was higher compared to results of II group, however, this difference is not statistically significant ( $p=0,442$, Mann-Whitney). LVMMI in III group was 53\% increased compared to I group ( $\mathrm{p}=0,005$, Mann-Whitney), in II group current index is increased compared to I for $41 \%$ ( $p=0,014$, Mann-Whitney). During comparison of results in II and III groups significant difference was not registered ( $\mathrm{p}=$ 0,256, Mann-Whitney) (Fig. 4).

\section{DISCUSSION}

In clinical research of polymorphic types of gene EDN1 that influence incresasoing of cardio-vascular diseases risk, we found that polymorphism of Lys198Asn gene of endothelin 1 is met more often. It is located in chromosome 6 p24p23 and includes 5 exons and 4 introns. Replacing of 
Table II. Median (interquartile range) of ECG indexes of left ventricular myocardium hypertrophy in patients with arterial hypertension, depending on body mass index.

\begin{tabular}{ccc}
\hline Group & Left Ventricular Mass, $\mathbf{g}$ & Left Ventricular Mass Index, $\mathbf{g} / \mathbf{m}^{\mathbf{2}, \mathbf{7}}$ \\
\hline І група $(\mathrm{n}=75)$ & $264(198-300)$ & $76(42-88)$ \\
\hline II група $(\mathrm{n}=48)$ & $267(200-319)$ & $79(44-89)$ \\
\hline III група $(\mathrm{n}=37)$ & $320(240-390)$ & $86(54-95)$ \\
\hline $\mathrm{p}$ (Kruskal-Wallis) & $\mathrm{p}<0,001$ & $\mathrm{p}=0,002$ \\
\hline
\end{tabular}

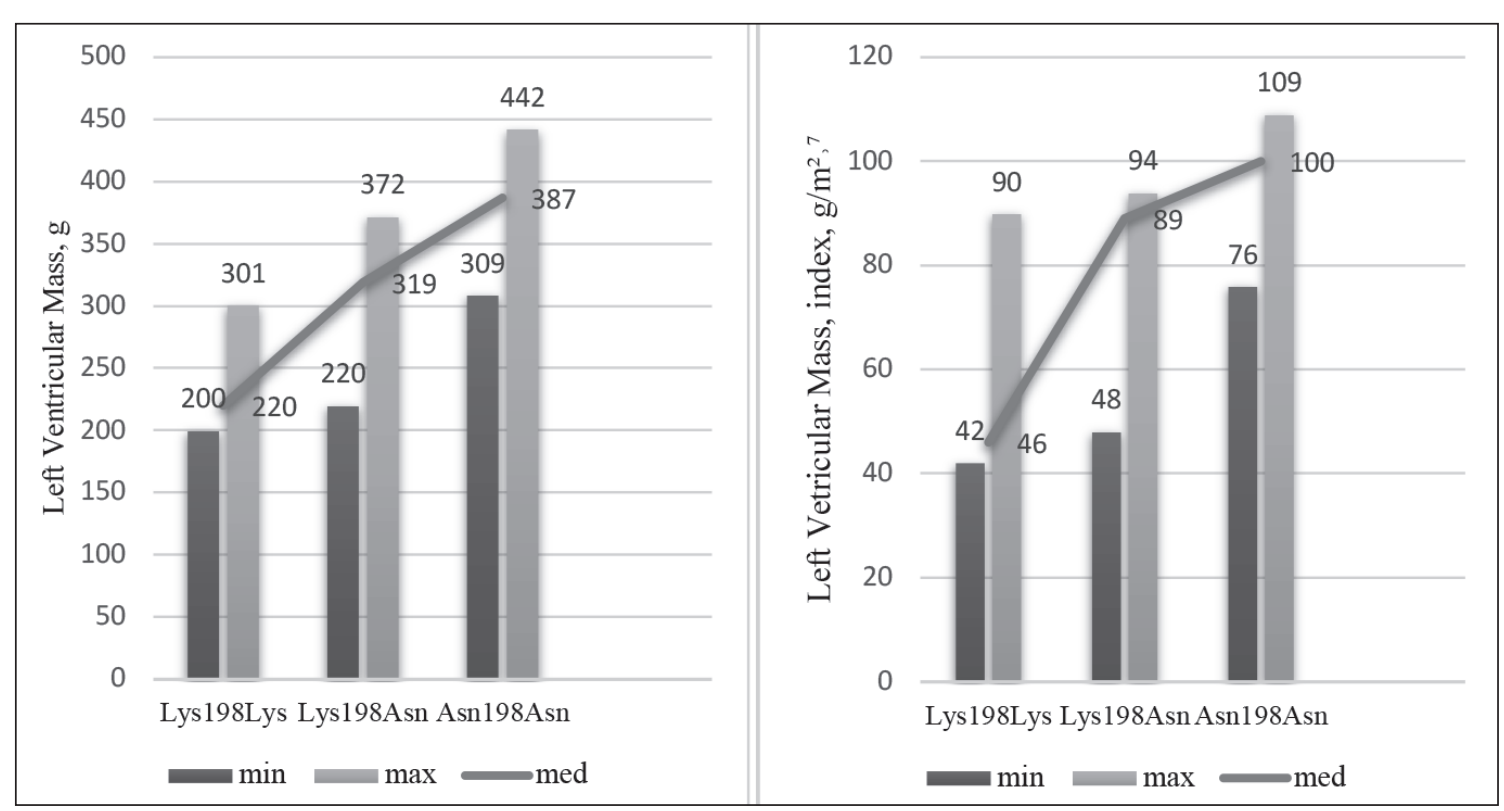

Fig. 2. Median (interquartile range) of ECG indexes in women depending on polymorphism of Lys198Asn in gene endothelin-1.

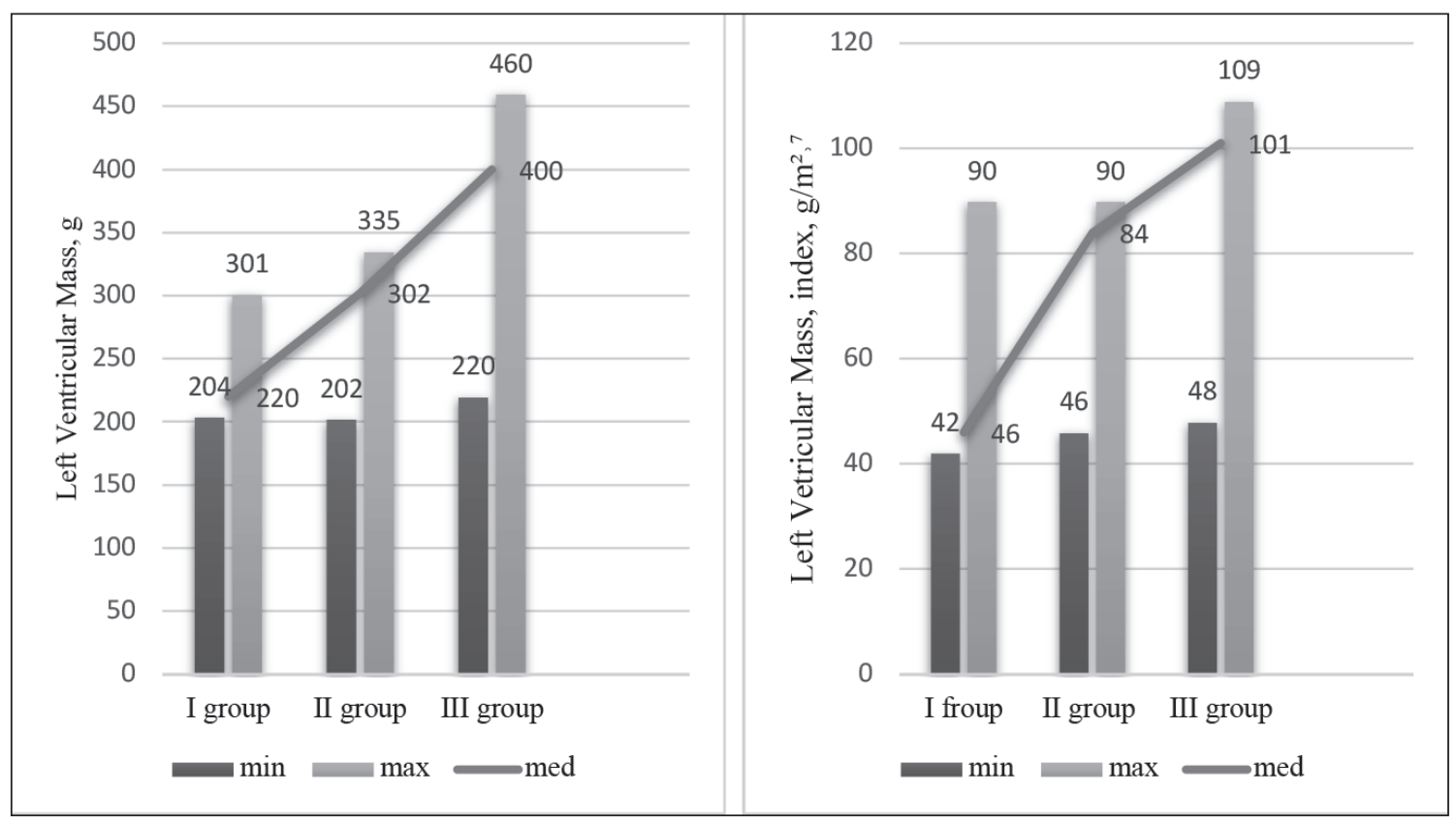

Fig. 3. Median (interquartile range) of ECG indexes of left ventricular myocardium hypertrophy in men with arterial hypertension, depending on BMI.

guanine to thymine in position 594 of nucleotide sequence $(594 \mathrm{G}>\mathrm{T})$ leads to replacing of amino-acid lysine (Lys) to asparagine (Asn) in codon of 198 polypeptide (Lys198Asn), and changes protein structure and activity $[11,12]$. Studying of polymorphic types of Lys198Asn gene of EDN1 was carried in cases of arterial hypertension, coronary heart disease (CHD), chronic heart failure (CHF), bloodstrokes, myocardial infraction. Current study was aimed to determine interconnection of gene's difference with heart diseases ' frequency, influence on disease mechanism, com- 


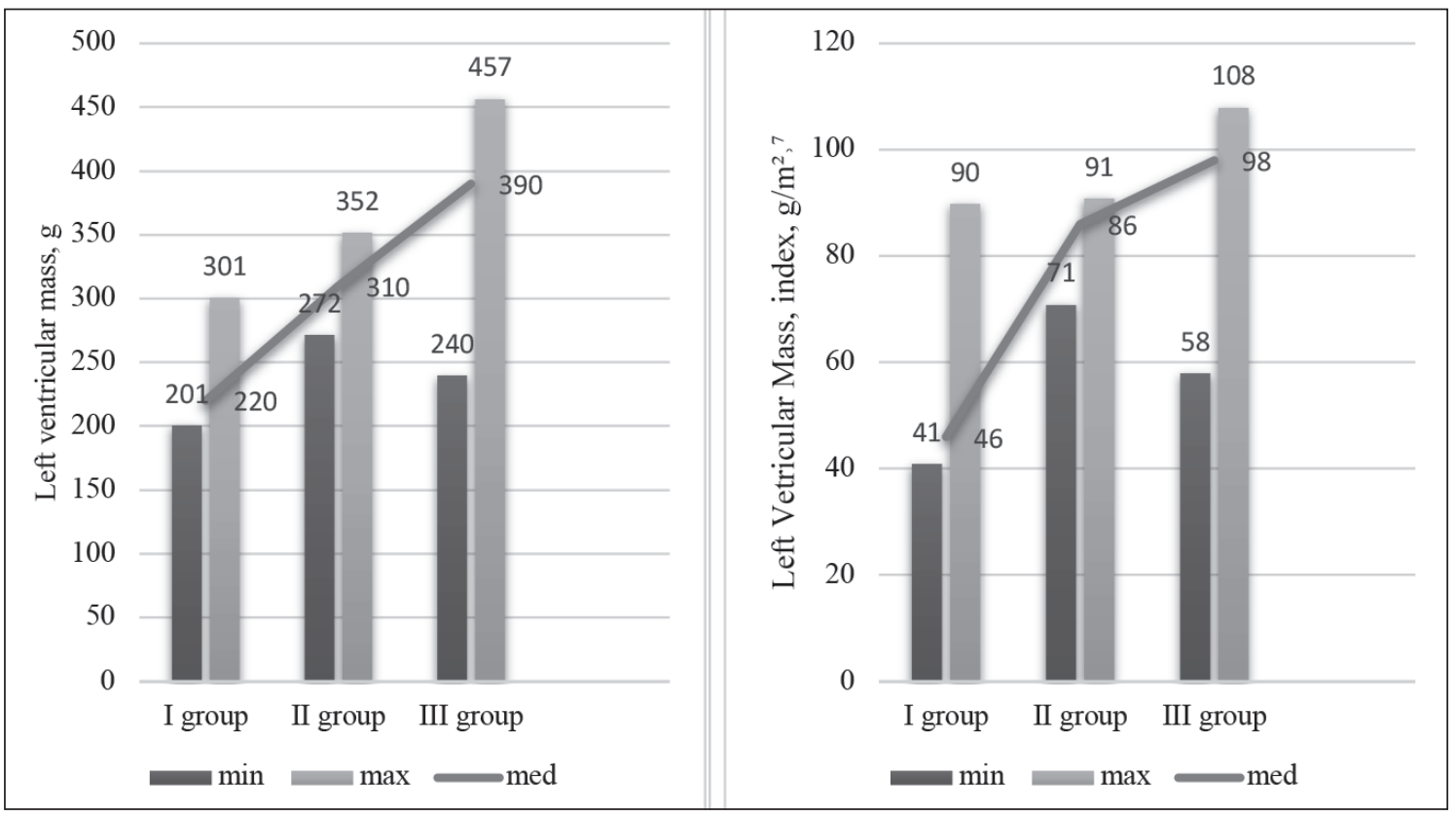

Fig. 4. Median (interquartile range) of ECG indexes of left ventricular myocardium hypertrophy in women with arterial hypertension, depending on BMI.

plications, progress, medical prognosis. Numerous previous studies proved dependence of genotype Asn198Asn, allele Asn and increased indexes of ET1 in blood, and lead us to believe that contingent of patients-carriers of allele Asn is a group of high cardio-vascular diseases risk [13, $14,15,16]$.

There are not much researches and studies of influence of polymorphism Lys 198Asn of gene endothelin-1 in development of left ventricular myocardium hypertrophy, changes of heart sizes and cavity volume, in other words, process of myocardium remodeling, presented. Palagnyuk GO, Zhebel' VM (2016) studied how carriage of allele Asn in patients with non-complicated hypertonia and complicated $\mathrm{CHF}$ was associated with negative changes of indexes of myocardium hypertrophy, left ventricular volume, LVEF, total peripheral resistance, diastolic function, systolic blood pressure, diastolic blood pressure, that increased correspondently to hypertension complication. Authors consider that patients with arterial hypertension, and carriers of allele Asn of gene endothelin-1 have negative prognosis of cardio disease and risk of CHF development [16]. Petyunina OV, Kopytsya MP (2018) studied clinical-genetic aspects of association of polymorphism of Lys198Asn of gene endothelin1 with development of early and late myocardium remodeling after suffering acute myocardial infraction with elevation of ST (AMIeST). In acuity of AMIeST structural and functional indexes of myocardium depending on Lys198Asn polymorphism of gene endothelin-1 were not changed. In 6 months carriers of genotypes Lys198Asn + Asn198Asn compared to ones with genotype Lys198Lys had increasing of size and left ventricular volume, LVMM, diameter of left auricle, thus, predisposition of progressive myocardium remodeling and CHF development were evidenced [17]. M.Colombo et al. (2006) studied dependence of Lys198Asn polymorphism of gene endothelin- 1 and $\mathrm{H} 323 \mathrm{H}$ of gene ET-A receptors with development of CHF in patients with LVEF $\leq 40 \%$. CHF risk was increasing in carriers of genotype Asn198Asn compared to allele Lys $(\mathrm{OR}=3,2 ; \mathrm{p}=0,03)$. In combination of carriage of homozygote Asn198Asn polymorphism of gene endothelin-1 and TT of gene ET-A CHF risk was highly increased $(\mathrm{OR}=8,6 ; \mathrm{p}=0,005)$, that led to decreasing of FVC and increasing of EDD compared to patients-carriers of homozygotes Lys and C of correspondent genes [18]. Correlation of allele Asn of gene endothelin-1 with left ventricular hypertrophy and arterial hypertension was also found in other studies $[19,20,21]$.

\section{CONCLUSIONS}

Analysis of dependence of ECG indexes from polymorphism of Lys198Asn of gene endothelin-1 allowed to determine that in patients-carriers of genotype Asn198Asn, LFMMI and LVMM are higher than in carriers of genotype Lys198Lys and Lys198Asn both in men and women. Analysis result of dependence of LVMMI and LVMM from BMI demonstrated that in patients with obesity these indexes are higher compared to patients with increased and normal body mass. Prospective of further research is determination of influence of mentioned polymorphism types on effectiveness of anti-hypertension therapy and decreasing of LVH level.

\section{REFERENCES}

1. Bauml M.A., Underwood D.A. Left ventricular hypertrophy: an overlooked cardiovascular risk factor. Cleveland Clin J Med. 2010; 77(6):381-387.

2. Artham S.M., Lavie C.J., Milani R.V., et al. Clinical impact of left ventricular hypertrophy and implications for regression. Prog Cardiovasc Dis. 2009; 52(2):153-167. 
3. Kannel W.B., Gordon T., Offutt D. Left ventricular hypertrophy by electrocardiogram. Prevalence, incidence, and mortality in the Framingham study. Ann. Intern. Med. 1969; 71:89 - 105.

4. Electrocardiography of Arrhythmias: A Comprehensive Review: A Companion to Cardiac Electrophysiology Paperback. 2012: 496, 45.

5. Jambric Z., Venneri L., Varga A. et al. Periferal vascular endothelial function testing for the diagnosis of coronary artery disease. Amer. Heart J. 2004; 41: 684-689.

6. The ESHRE Capri Workshop Group. Hormones and cardiovascular health in women. Human Report Update. 2006; 12: 483-497.

7. Khare A., Shetty S., K. Ghosh K. Evaluation of markers of endothelial damage in case of young myocardial infarction. Atherosclerosis. 2005; 18: $375-380$.

8. Nystrom T., A. Nygren A., Sjoholm A. Persistent endothelial dysfunction is related to elevated C-reactive protein levels in type II diabetic patients after acute myocardial infarction. Clin. Science. 2005; 12: 121-128.

9. Cuspidi C., Sala C., Valerio C., et al. Nocturnal hypertension and organ damage in dippers and nondippers. Am J Hypertens. 2012 Aug; 25(8):869-75. doi: 10.1038/ajh.2012.49. Epub 2012 May 10.

10. Wong C., O'Moore-Sullivan T., Byr-ne N. et al. Weight reduction improves subclinical myocardial and vascular dysfunction in obese subjects. Eur. Heart J. 2005; 26: 340.

11. Ahmed M., Rghigh A. Polymorphism in Endothelin-1 Gene: An Overview. Curr. Clin. Pharmacol. 2016; 11 (3): 191-210. PMID: 27397091. doi: 10. 2174/1574884711666160701000900.

12. Popov A.F., Schulz E.G., Hinz J. et al. Impact of endothelin-1 Lys198Asn polymorphism on coronary artery disease and endorgan damage in hypertensives. Coron. Artery Dis. 2008; 19 (7): 429—434. doi: 10.1097/ MCA.0b013e32830936e5

13. TeplyakovA.T., BerezikovaE.N.,ShilovS.N.Serdechnaya nedostatochnost’ Kliniko-geneticheskie aspekty` ishemicheskogo remodelirovaniya i apoptoza miokarda v razvitii serdechnoj nedostatochnosti [Clinicalgenetic aspects of ischemic remodeling and apoptosis of myocardium in development of cardiac failure]. Tomsk: STT. 2015; 400. (Ru)

14. Feoktistova V.S., Lipunova A.S., Kolesnichenko M.G. i dr. Polimorfizm genov e 'ndotelial'noj N0-sintazy', e`ndo telina-1 kak faktor riska kardial nogo sindroma Kh u zhenshhin [Polymorphism of genes of endothelium N0-synthetase, endothelin-1 as factor of development of cardial syndrome KH in women]. Problemy` zhenskogo zdorov ya. 2012; 3 (7): 24-29. (Ru)

15. Dhawan I., Choudhury M., Hote M.P. et al. Is Endothelin Gene Polymorphism Associated with Postoperative Atrial Fibrillation in Patients Undergoing Coronary Artery Bypass Grafting?. Ann. Card. Anaesthesia.2017; 20 (3):341-347.doi.org/10.4103/aca.ACA_264_

16. Palahniuk H.O., Pashkova I.I., Zhebel V.M. et al. Gene polymorphism of ET-1 and its plasma levels in men with uncomplicated essential hypertension and left ventricular hypertrophy. Biological Markers and Guided Therapy. 2016; 3: 45-46. doi: 0.13140/RG.2.1.4823.9768

17. Petyuni`na 0.V., Kopiczya M.P., Gal’chins`ka V.Yu., Pyetyen `ova L.L. Osoblivosti remodelyuvannya serczya u khvorikh, shho perenesli gostrij i 'nfarkt mi`okarda z elevaczi yeyu segmenta ST, zalezhno vi d poli'morfi zmu Lys198Asn gena endoteli'nu-1 [Specifics of heart remodeling in patients, who suffered myocardium infraction with elevation of ST-segment, depending on polymorphism of Lys198Asn of gene endothelin-1]. Ukrayins ' kij terapevtichnij zhurnal. 2018; 3-4: 40-47. (UA)
18. Colombo M.G., Ciofini E., Paradossi U. et al. ET-1 Lys198Asn and $\mathrm{ET}(\mathrm{A})$ receptor $\mathrm{H} 323 \mathrm{H}$ polymorphisms in heart failure. A casecontrol study. Cardiology. 2006; 105 (4): 246-252. Epub 2006 Mar 30. doi:10.1159/000092374.

19. Illyash M.G., Andrushhenko T.A., Basanecz` A.V., Doli`nchuk L.V. Molekulyarno-genetichnij anali' z gi pertrofi yi mi okarda v shakhtari` vugi' I’nikh shakht Ukrayini [Molecular-genetic research of myocardium hypertrophy in miner of Ukraine]. Ukr. kardi ol. zhurn. 2014;1: 50-55. (UA)

20. Minushkina L.0. Geneticheskie faktory` pri gipertonicheskoj bolezni: svyaz` s osobennostyami techeniya, razvitiem oslozhnenij, e`ffektivnost yu terapii: dis... dokt. med. nauk. [Genetic factors of hypertonia disease: connection with clinical process, development of complications, therapy effectiveness: dissertation of Doctor of Medicine]. Moscow. 2008; 186. (Ru)

21. Peng T., Hu Z., Wu L. et al. Correlation between endothelial dysfynction and left ventricular remodeling in patients with chronic kidney disease. Kidney Blood Res. 2014; 39 (5): 420—426. doi: 10.1159/000368455.

Presented article was performed in framework of research "Molecular-genetic and morphological features of tissue regeneration of lower limb in conditions of chronic hyperglycemia», state registration № 0117U003926.

\section{Funding:}

The study was performed with financial support from the Sumy State University.

\section{ORCID and contributionship:}

Yuliia O. Smiianova - 0000-0002-8782-0559 B,C,D,F

Liudmyla N. Prystupa - 0000-0002-6454-9831 A,F

Olha M. Chernatska - 0000-0001-9093-6862 ${ }^{\mathrm{E}}$

Yurii V. Smiianov - 0000-0002-3311-4210 C

\section{Conflict of interest:}

The Authors declare no conflict of interest

\section{CORRESPONDING AUTHOR Yuliia 0.Smiianova \\ Sumy State University \\ Rymskoho-Korsakova St., 2, 40007, Sumy, Ukraine \\ tel: +380996098329 \\ e-mail: smijanova@ukr.net}

Received: 28.01 .2020

Accepted: 02.04 .2020

\footnotetext{
A - Work concept and design, B - Data collection and analysis, C - Responsibility for statistical analysis, D-Writing the article, $\mathbf{E}$-Critical review, $\mathbf{F}$ - Final approval of the article
} 